\title{
Communication
}

[Comunicação]

\section{Metacercariae of Diplostomum compactum Lutz, 1928 (Trematoda, Diplostomidae) in the eyes of acara Geophagus brasiliensis Quoy \& Gaimard, 1824 (Teleostei, Cichlidae) from Barra Bonita Reservoir - São Paulo, Brazil}

[Metacercária do Diplostomum compactum Lutz, 1928 (Trematoda: Diplostomidae) em olhos de acará Geophagus brasiliensis Quoy \& Gaimard, 1824 (Teleostei: Cichlidae) no reservatório de Barra Bonita - São Paulo]

\author{
J.L.C. Novaes ${ }^{1,2,4}$, I.P. Ramos ${ }^{2}$, E.D. Carvalho ${ }^{2}$, R.J. Silva ${ }^{3}$ \\ ${ }^{1}$ Aluno de pós-graduação - UNESP - Botucatu, SP \\ ${ }^{2}$ Departamento de Morfologia - UNESP \\ Distrito de Rubião Junior, \\ 18618-000 - Botucatu, SP \\ ${ }^{3}$ Departamento de Parasitologia - UNESP - Botucatu, SP \\ ${ }^{4}$ Bolsista de CAPES
}

Trematodes of the genus Diplostomum have been found in different hosts from several countries (Kohn et al., 1995). Diplostomum compactum presents a wide geographic distribution, for example, in the Mexico, Venezuela and Nicaragua, and has already been reported infecting species of native fish as Rhamdia guatemalensis (Günther, 1864), and also exotic as, Oreochromis aureus (Steindachner, 1864) and O. mossambicus (Peters, 1852) (Perez-Ponce de Leon et al., 1992; Garcia et al., 1993; Branches, 1995; Aragort et al., 1997; Aguirre-Macedo, 2001).

In Brazil, metacercariae of D. compactum have been registered in Plagioscion squamosissimus (Heckel, 1840), Cichla monoculus Spix \& Agassiz 1831, Hoplias malabaricus (Bloch, 1794) and Satanoperca pappaterra (Heckel, 1840) from the high Paraná River and Itaipu reservoir, in the South of Brazil (Kohn et al., 1995; Pavanelli et al., 2000). In Tietê River basin, metacercariae were found in P. squamosissimus only in the Nova Avanhandava reservoir (Paes et al., 2003). The aim of this study was to report the occurrence of this trematode in Geophagus brasiliensis (Teloestei: Cichlidae) from Barra Bonita reservoir, Tietê River, São Paulo State, Brazil.

During studies on the fish landings of Barra Bonita reservoir, Tietê River, a specimen of G. brasiliensis presented its eyes infected by small trematodes. The previous morphologic analysis of the parasites suggested that they were metacercariae of Diplostomum.

The fish was taken to laboratory where the metacercariae were removed from the vitreous humour and fixed in AFA solution after flattening. In toto preparations were accomplished for five trematode specimens stained with carmine. The morphological and morphometrical analysis were performed using a computerized system for image analysis (QWin Lite 2.5 - Leica). The values represent the mean and range (minimummaximum) of five parasite specimens.

The metacercariae presented: foliaceous body, slightly concave in the ventral face, $1800 \mu \mathrm{m}$ (1584$1947 \mu \mathrm{m})$ long and $642 \mu \mathrm{m}(537-709 \mu \mathrm{m})$ wide, and small conical segment in posterior region (Fig.1); a small subterminal oral sucker $59 \mu \mathrm{m}(45-83 \mu \mathrm{m})$ long $68 \mu \mathrm{m}(54-77 \mu \mathrm{m})$ wide, two lateral pseudosuckers in the anterior region; oval pharynx $61 \mu \mathrm{m}$ $(53-73 \mu \mathrm{m})$ long $56 \mu \mathrm{m}(50-64 \mu \mathrm{m})$ wide; short esophagus; intestinal caeca ending near to posterior region; oval holdfast (tribocytic organ) $428 \mu \mathrm{m}$ (422-434 $\mu \mathrm{m})$ long $258 \mu \mathrm{m}(220-319 \mu \mathrm{m}) \mu \mathrm{m}$ wide. Gland cells occupying most of anterior region, extending from the beginning of intestinal caeca to anterior region of tribocytic organ and small gonads in posterior region, after tribocytic organ, were observed.

Recebido em 30 de março de 2005

Aceito em 7 de agosto de 2006

E-mail: novaes@ibb.unesp.br 


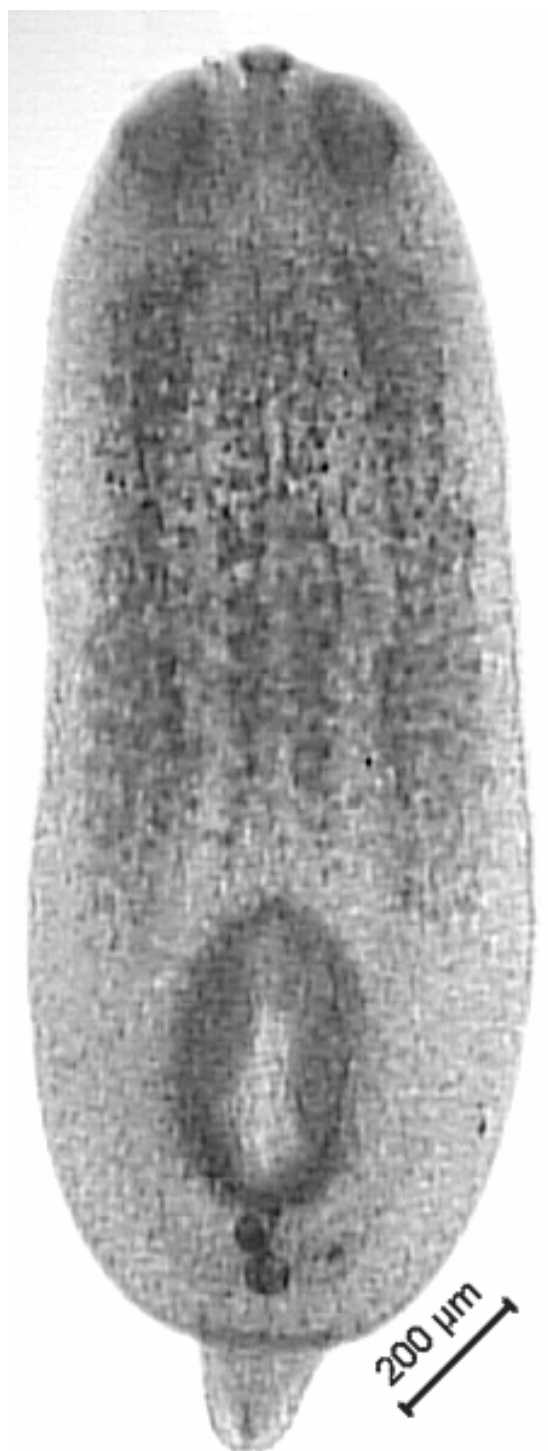

Figure 1. Metacercariae of Diplostomum compactum (Trematoda: Diplostomidae) collected in a specimen of Geophagus brasiliensis (Teleostei: Cichlidae) from Barra Bonita reservoir, Tietê River, São Paulo State, Brazil.

The observed characteristics allowed concluding that the species found in the eye of $G$. brasilienses is Diplostomum compactum. The morphological and morphometrical data are in accordance with the description of this trematode species (Kohn et al., 1995). This is the first report of its occurrence in G. brasiliensis. In Brazil, the metacercariae of $D$. compactum have been previously reported in $P$. squamosissimus, C. monoculus, $H$. malabaricus, and $S$. pappaterra (Kohn et al., 1995; Pavanelli et al., 2000; Paes et al., 2003). This is a new host record for $D$. compactum.
Metacercariae of other species of the family Diplostomidae have been causing mortality of the catfish (Ictalurus punctatus) in the Southeast United State of America farms (Overstreet and Curran, 2004). Silva and Souza (1998) found metacercariae of $D$. compactum infecting the posterior ocular chamber of $P$. squamosissimus and observed no inflammatory reaction or other histological alterations associated with the parasite. However, according this author, the fish health condition was influenced by the parasite and the relative condition factor $(\mathrm{Kn})$ was worse in the parasitized fishes. In the reservoir of Barra 
Borrifa the metacercariae would be potentially dangerous for the tilapia of Nile (Oreochromis niloticus), because that species represents $85 \%$ of the fishing production of that reservoir (Novaes et al., 2005), what could cause a high impact in the local economy.

Keywords: acará, Geophagus brasiliensis,

Diplostomum compactum, Diplostomidae, Brazil

\section{RESUMO}

Relata-se a ocorrência de metacercárias de Diplostomum compactum (Trematoda: Diplostomidae) infectando Geophagus brasiliensis (Teleostei: Cichlidae) do reservatório de Barra Bonita, rio Tietê, estado de São Paulo, Brasil. As metacercárias foram coletadas no globo ocular, fixadas em solução de AFA e coradas com carmim. As análises morfológicas e morfométricas de cinco espécimes foram realizadas por meio do sistema computadorizado de analise de imagem. Este foi o primeiro registro da ocorrência desse parasito no reservatório de Barra Bonita e também o primeiro registro em acará Geophagus brasiliensis.

Palavras-chave: acará, Geophagus brasiliensis, Diplostomum compactum, Diplostomidae, Brasil

\section{REFERENCES}

AGUIRRE-MACEDO, M.L.; SCHOLZ, T.; GONZÁLEZ-SOLÍS, D. et al. Larval helminths parasitizing freshwater fish from the Atlantic coast of Nicarágua. Comp. Parasitol., v.68, p.42$51,2001$.

ARAGORT, F.W.; LEON, A.E.; GUILLEN, A.T. et al. Fauna parasitaria en las tilapias del lago Valencia. Vet. Trop., v. 22, p.171-187,1997.

GARCIA, M.L.J.; OSORIO-SARAIBA, D.; CONSTATINO, F. Prevalencia de los parasitos y las alteraciones histológicas que producen a las tilapias de la laguna de Amela Tecoman, Colima. Vet. México, v.24, p.199-205, 1993.

KOHN, A.; FERNANDES, B.M.M.; BAPTISTA FARIAS, M.F.D. Metacercariae of Diplostomum (Austroplostomum) compactum (Trematoda, Diplostomidae) in the eyes of Plagioscion squamosissimus (Teleostei, Sciaenidae) from the reservoir of the Hydroelectric Power Station of Itaipu, Brazil. Mem. Inst. Oswaldo Cruz, v.90, p.341-344, 1995.

NOVAES, J.L.C.; CARVALHO, E.D.; RAMOS, I.P. et al. Avaliação do desembarque pesqueiro em duas colônias de pescadores na represa de Barra Bonita (Rio Tietê, SP): Resultados preliminares. In: ENCONTRO BRASILEIRO DE ICTIOLOGIA, 16., 2005, João Pessoa. Anais..., João Pessoa, 2005. p. 229. (Resumo).
OVERSTREET, R.M.; CURRAM, S.S. Defeating diplostomoid dangers in USA catfish aquaculture. Fol. Parasitol., v.51, p.153-165, 2004.

PAES, J.V.K.; SANTOS, K.R; CARVALHO, E.D. et al. da. Ocorrência de metacercária de Diplostomum compactum (Trematoda, Diplostomidae) parasitando Plagioscion squamosissimus (Teleostei, Sciaenidae) proveniente do reservatório de Nova Avanhandava, Buritama, São Paulo. Arq. Inst. Biol., v.70, p.383-387, 2003.

PAVANELLI, G.C.; TAKEMOTO, R.M.; MACHADO, P.M. et al. Componentes biológicos: ictioparasitologia, 173-181. 2000. Disponível em: $<$ http://www.peld.uem.br/Relat2000/peldsumario.htm/>. Acesso em: 5 jan. 2005.

PEREZ-PONCE DE LEON, G.; OSORIOSARAIBA, D.; GARCIA-PRIETO, L. Hemiltofauna del "Juile" Rhambdia guatemalensis (Pisces: Pimelodidae), del lago de Catemaco, Veracruz. Rev. Soc. Mex. Hist. Nat., n.43, p.25-31, 1992.

SILVA E SOUZA, A.T. Estudo do parasitismo de Plagioscion squamosissmus (Heckel, 1940) (Perciformes, Sciaenidae) por Diplostomum (Austrodiplostomum) compactum (Lutz, 1928) (Trematoda, Digenea) no Rio Tibagi, PR. 1998. 125f. Tese (Doutorado) - Universidade Federal de São Carlos, São Carlos, SP. 